\title{
Effect of Different Types of Biochar Application on Secondary and Micronutrients Content and Uptake by Fodder Maize
}

\author{
Naresh K. Yadav ${ }^{1}$, Rajkishore Kumar ${ }^{1}$, Subodh K. Bishnoi ${ }^{2 *}$ and P. C. Patel ${ }^{3}$ \\ ${ }^{1}$ Dept. of Soil Science and Agricultural Chemistry, Bihar Agricultural University, Sabour, Bihar (813 210), India \\ ${ }^{2}$ Dept. of Plant Physiology, Agricultural Research Station, Sriganganagar, SKRAU, Bikaner, Rajasthan (335 001), India \\ ${ }^{3}$ Agricultural Research Station, Sansoli, Gujarat (387 130), India
}

\section{Article History}

Manuscript No. AR821

Received in $27^{\text {th }}$ June, 2014

Received in revised form $15^{\text {th }}$ April, 2015

Accepted in final form $4^{\text {th }}$ June, 2015

\section{Correspondence to}

"E-mail: bishnoisk2@gmail.com

\section{Keywords}

Biochar, maize, FYM, Ca, Mg, S, Zn, Fe, $\mathrm{Cu}, \mathrm{Mn}$

\begin{abstract}
An investigation was carried out to study the effect of three biochar applications viz., maize stover (MS), cluster bean stover (CB) and Prosopis julifera wood (PJ) and one farm yard manure (FYM) on secondary and micronutrients content and uptake by fodder maize during 2010-11 and 2011-12. The biochar and FYM both were applied (a) $5 \mathrm{t}$ and $10 \mathrm{t} \mathrm{ha}^{-1}$. The recommended dose of fertilizer (RDF) (80-40-0 kg ha-1 $\mathrm{N}-\mathrm{P}-\mathrm{K}$ ) was applied in eight treatments and remaining eight treatments comprised of biochar and FYM. The Zn and Fe were applied in form of $\mathrm{ZnSO}_{4} @ 20 \mathrm{~kg} \mathrm{ha}^{-1}$ and $\mathrm{FeSO}_{4} @ 40 \mathrm{~kg} \mathrm{ha}^{-1}$, respectively in all treatments as basal. There was a significant increase in the S and Mn concentration with the application of CB biochar@ $5 \mathrm{t} \mathrm{ha}^{-1}$ without RDF and with RDF significantly increased the Mg concentration in maize. Application of PJ biochar@ $5 \mathrm{t} \mathrm{ha}^{-1}$ along with RDF significantly increased Ca, Zn and Fe concentration and FYM@ $9 \mathrm{tha}^{-1}$ along with RDF resulted in the highest $\mathrm{Cu}$ concentration in maize. Nutrient uptake like $\mathrm{Ca}, \mathrm{Mg}, \mathrm{S}, \mathrm{Cu}$, higher removals of $\mathrm{Zn}$ and $\mathrm{Fe}$ in maize and highest available $\mathrm{Ca}$ and $\mathrm{Mg}$ content were significantly increased with the application of RDF+MS10 while the uptake of Mn and DTPA extractable $\mathrm{Zn}, \mathrm{Cu}, \mathrm{Mn}$ and $\mathrm{Fe}$ content in soil were significantly increased with the application of RDF+MS5. CB biochar@ $10 \mathrm{t} \mathrm{ha}^{-1}$ along with RDF showed significantly the highest available $\mathrm{S}$ content in soil.
\end{abstract}

\section{Introduction}

Biochar can be described as a kind of charcoal made from the pyrolysis of a range of biomass feedstocks, including crop, wood and yard wastes, and manures (Novak et al., 2009). "Biochar is the porous carbonaceous solid produced by thermo chemical conversion of organic materials in oxygen depleted atmosphere which has physiochemical properties suitable for safe and potentially soil improvement" (Steinbeiss et al., 2009). Currently, very little biochar material is being used in agriculture in India and elsewhere. Therefore, in the future development in crop production with biochars, agronomic values of these products in terms of crop response and soil health benefits need to be quantified. Beneficial effects of biochar in terms of increased crop yield and improved soil quality have been reported (Iswaran et al., 1980; Glaser et al. 2002). However, review of previous research showed a huge range of biochar application rates $\left(0.5-135 \mathrm{tha}^{-1}\right.$ of biochar) as well as a huge range of plant responses (-29-324\%) (Glaser et al., 2002). More importantly, in much of this research, properties of the biochar used in the investigation were not reported.

It is important to understand that biochar is not an actual fertiliser although at times it can supply nutrients to plants, for example calcium, magnesium, sulphur and micronutrient. Biochar is usually limiting in poor soils and the ash from biochar could explain the strong effect of biochar on maize biomass yield especially in coarse texture soil soon after application. Keeping the above facts in mind, the following study has been carried out.

\section{Materials and Methods}

An experiment was carried out during the Kharif of 201011 and 2011-12 at Agricultural Research Station, Sansoli, district, Kheda, Anand Agricultural University, Gujarat. The experimental soil (Typic Ustochrept) was sandy loam in 
texture, having pH 8.10, EC $0.15 \mathrm{dSm}^{-1}$, organic carbon $0.24 \%$, available $\mathrm{N} 200 \mathrm{~kg} \mathrm{ha}^{-1}, \mathrm{P}_{2} \mathrm{O}_{5} 30 \mathrm{~kg} \mathrm{ha}^{-1}$ and $\mathrm{K}_{2} \mathrm{O} 150 \mathrm{~kg} \mathrm{ha}^{-1}$. The physical properties of soil sample analysis followed by mechanical analysis (International pipette method) at 0 to 25 cm depth containing clay $4.71 \%$, silt $11.52 \%$, fine sand $0.54 \%$, Available Ca 800 ppm, Available Mg 750 ppm, Available S $8.2 \mathrm{mg} \mathrm{kg}^{-1}$, Micro-nutrients (0.005 M DTPA-ex-tractable) $\mathrm{Fe}, \mathrm{Mn}, \mathrm{Zn}$, and $\mathrm{Cu} 4.50,10.62,0.40$ and $1.20 \mathrm{mg} \mathrm{kg}^{-1}$. The initial chemical status of different biochar such as maize stover biochar, Cluster bean stover biochar and Prosopis julifera biochar were also analysed along with 16 treatments combination which is depicted in (Table 1 and 2). Full dose of $\mathrm{P}\left(40 \mathrm{~kg} \mathrm{P}_{2} \mathrm{O}_{5} \mathrm{ha}^{-1}\right)$ in the form of Single Super phosphate and $50 \%$ of $\mathrm{N}\left(40 \mathrm{~kg} \mathrm{~N} \mathrm{ha}^{-1}\right)$ in the form of urea were applied in furrows at the time of sowing as per treatment. Remaining $50 \% \mathrm{~N}\left(40 \mathrm{~kg} \mathrm{~N} \mathrm{ha}^{-1}\right)$ was applied in the form of urea as topdressing at 30 days after sowing. A common dose of $\mathrm{ZnSO}_{4}$ @ $20 \mathrm{~kg} \mathrm{ha}^{-1}$ and $\mathrm{FeSO}_{4} @ 40 \mathrm{~kg} \mathrm{ha}^{-1}$ was applied in furrows in all the plots at the time of sowing. The representative soil samples from $0-25 \mathrm{~cm}$ depth were collected from each plot after the harvest of maize crop as per standard procedure. After harvest of the crop, whole plant samples (shoot along with leaves) were washed with dilute $0.01 \mathrm{~N} \mathrm{HCl}$, single and double deionised water in a sequence and air dried. Then samples were dried in a hot air oven in paper bags at $70^{\circ} \mathrm{C}$ till constant weight obtained and preserved for further analysis. These samples were ground in a stainless steel Willey mill to avoid contamination of micronutrients and were preserved in air tight polyethylene bags for further analysis. The processed soil samples were analyzed initially and after the completion of the experiment for important soil properties viz. available nutrients viz., $\mathrm{Ca}$, $\mathrm{Mg}, \mathrm{S}, \mathrm{DTPA}$ extractable micronutrients ( $\mathrm{Zn}, \mathrm{Fe}, \mathrm{Mn}$ and $\mathrm{Cu}$ ).

Table 1: Chemical properties of the biochar used in the experimental field

\begin{tabular}{|c|c|c|c|c|}
\hline $\begin{array}{l}\text { S1. } \\
\text { no. }\end{array}$ & Properties & $\begin{array}{l}\text { Maize } \\
\text { stover }\end{array}$ & $\begin{array}{c}\text { Cluster } \\
\text { bean } \\
\text { stover }\end{array}$ & $\begin{array}{c}\text { Prosopis } \\
\text { julifera } \\
\text { wood }\end{array}$ \\
\hline \multicolumn{5}{|c|}{ Chemical properties } \\
\hline 1. & $\mathrm{pH}(1: 2.5)$ & 8.6 & 8.1 & 8.2 \\
\hline 2. & CEC & 35 & 25 & 18 \\
\hline 3. & $\mathrm{Ca}$ content $\left(\mathrm{g} \mathrm{kg}^{-1}\right)$ & 3.25 & 2.60 & 2.10 \\
\hline 4. & $\operatorname{Mg}$ content $\left(\mathrm{g} \mathrm{kg}^{-1}\right)$ & 2.34 & 2.28 & 1.90 \\
\hline 5. & S content $(\%)$ & 0.23 & 0.73 & 0.59 \\
\hline 6. & $\mathrm{Zn}\left(\mathrm{mg} \mathrm{kg}^{-1}\right)$ & 42.15 & 39.36 & 38.15 \\
\hline 7. & $\mathrm{Fe}\left(\mathrm{mg} \mathrm{kg}^{-1}\right)$ & 310.12 & 218.15 & 201.24 \\
\hline 8. & $\mathrm{Cu}\left(\mathrm{mg} \mathrm{kg}^{-1}\right)$ & 4.75 & 4.35 & 4.10 \\
\hline 9. & $\operatorname{Mn}\left(\mathrm{mg} \mathrm{kg}^{-1}\right)$ & 40.35 & 36.15 & 34.15 \\
\hline & $\mathrm{C}: \mathrm{N}$ ratio & 30.06 & 35.28 & 70.0 \\
\hline
\end{tabular}

In plant analysis $\mathrm{S}$ was estimated by Turbiditmetric methods. The $\mathrm{Ca}$ and $\mathrm{Mg}$ were estimated by Versanate titration method (Cheng and Bray, 1951). The micronutrients ( $\mathrm{Fe}, \mathrm{Cu}, \mathrm{Mn}$ and Zn) were estimated by Atomic Absorption Spectrophotometer (Lindsay and Norvell, 1978). The dried plant samples (leaf and straw) were ground in a stainless steel blade Willey mill and digested in Di-acid mixture $\left(\mathrm{HNO}_{3}: \mathrm{HClO}_{4}-4: 1\right.$ ratios) as per standard procedure (Jackson, 1973). The data obtained for above mention different parameters was subjected to statistical analysis as per the method suggested by Gomez and Gamer (1984) for RBD design.

\section{Results and Discussion}

\subsection{Micronutrient content and uptake}

\subsubsection{Zinc (Zn)}

The zinc concentration in maize shoot was significantly influenced by the application of biochar (MS, CB and PJ) and FYM@5 and $10 \mathrm{t}$ with and without RDF treatments in both the year (2011 and 2012) as well as pooled basis. However, the lowest $\mathrm{Zn}$ content in maize shoot was found in unfertilized treatment in 2011 and 2012 as well as polled basis. The interaction was found non-significant between year and treatment. The highest $\mathrm{Zn}$ concentration of maize plant showed in treatment of $\mathrm{RDF}+\mathrm{PJ}_{5}$ in first year and $2^{\text {nd }}$ year as well as pooled basis (Table 3 ). The application of biochar (MS, $\mathrm{CB}$ and $\mathrm{PJ}$ ) with and without fertilizer treatments decreased in $\mathrm{Zn}$ concentration of maize plant with increasing the rate of biochar from $5.0 \mathrm{t} \mathrm{ha}^{-1}$ to $10.0 \mathrm{t} \mathrm{ha}^{-1}$. Similar results were also true in unfertilized FYM application treatment. It might be due to higher dry matter production with the increasing rate of biochar and FYM from $5.0 \mathrm{t} \mathrm{ha}^{-1}$ to $10.0 \mathrm{t} \mathrm{ha}^{-1}$. The application of $\mathrm{RDF}+\mathrm{FYM}_{10}$ recorded significantly higher $\mathrm{Zn}$ uptake followed by $\mathrm{RDF}+\mathrm{MS}_{5}, \mathrm{RDF}+\mathrm{MS}_{10}, \mathrm{RDF}+\mathrm{CB}_{5}$ and

\begin{tabular}{ll}
\hline \multicolumn{2}{l}{ Table 2: Treatment details } \\
\hline (A) & Fertility levels (2) \\
\hline 1. & Control (AC) \\
2. & Recommended dose of fertilizer (RDF), $\left(\mathrm{N}_{2} \mathrm{P}_{2} \mathrm{O}_{5}: \mathrm{K}_{2} \mathrm{O}\right):$ \\
& $80-40-0 \mathrm{~kg} \mathrm{ha}^{-1}$ \\
\hline (B) Level of biochar (8) \\
\hline 1. & $5 \mathrm{t}$ biochar of cluster bean stover $\left(\mathrm{CB}_{5}\right)$ \\
2. & $5 \mathrm{t}$ biochar of maize stover $\left(\mathrm{MS}_{5}\right)$ \\
3. & $5 \mathrm{t}$ biochar of Prosopis julifera wood $\left(\mathrm{PJ}_{5}\right)$ \\
4. & $10 \mathrm{t}$ biochar of cluster bean stover $\left(\mathrm{CB}_{10}\right)$ \\
5. & $10 \mathrm{t}$ biochar of maize stover $\left(\mathrm{MS}_{10}\right)$ \\
6. & $10 \mathrm{t}$ biochar of Prosopis julifera wood $\left(\mathrm{PJ}_{10}\right)$ \\
7. & $5 \mathrm{t}$ Farm Yard Manure $\left(\mathrm{FYM}_{5}\right)$ \\
8. & $10 \mathrm{t}$ Farm Yard Manure $\left(\mathrm{FYM}_{10}\right)$ \\
\hline
\end{tabular}


$\mathrm{RDF}+\mathrm{CB}_{10}$. It indicated that biochar application in presence of fertilized soil significantly influenced the $\mathrm{Zn}$ uptake of maize crop. It might be due to higher dry matter yield. The result indicated that there was a positive significant correlation $\left(\mathrm{r}=0.980^{* *}\right)$ with an increase in rate of biochar and fertilized treatments of $\mathrm{Zn}$ uptake and dry matter yield of maize plants (Lehamann et al., 2003).

\subsection{2. $\operatorname{Iron}(\mathrm{Fe})$}

The application of biochar (MS, CB and PJ) and FYM @ 5 and $10 t$ with and without RDF treatment had significant effect (Table 3) on Fe concentration of maize plant in both the year (2011 and 2012) as well as pooled basis. The interaction was found non-significant between year and treatment. The application of biochar (MS, CB and PJ) with and without RDF treatments remarkably decreased in Fe concentration of maize plant with increase in the rate of biochar application from $5.0 \mathrm{t} \mathrm{ha}^{-1}$ to $10.0 \mathrm{t} \mathrm{ha}^{-1}$. It might be due to higher dry matter production with the higher rate of biochar and FYM. Similar results were also reported by Randon et al. (2007). Application of RDF+FYM 10 recorded remarkably higher Fe uptake of maize plant $\left(3030.49 \mathrm{~g} \mathrm{ha}^{-1}\right)$ followed by RDF+MS ${ }_{5}$ RDF+MS 10 and $\mathrm{RDF}+\mathrm{CB}_{10}$. It indicated that biochar application in presence of fertilized significantly influenced the Fe uptake of maize crop. It might due to higher dry matter yield. Similar results were also reported by Randon et al. (2007).

\subsubsection{Manganese (Mn)}

Application of biochar (MS, CB and PJ) and FYM @ 5 and $10 \mathrm{t}$ with and without RDF treatments have significant influence

\begin{tabular}{|c|c|c|c|c|c|c|c|c|c|c|c|c|}
\hline \multirow[b]{3}{*}{ Treatment } & \multicolumn{6}{|c|}{$\mathrm{Zn}$} & \multicolumn{6}{|c|}{$\mathrm{Fe}$} \\
\hline & \multicolumn{3}{|c|}{ Content $\left(\mathrm{mg} \mathrm{kg}^{-1}\right)$} & \multicolumn{3}{|c|}{ Uptake $\left(\mathrm{g} \mathrm{ha}^{-1}\right)$} & \multicolumn{3}{|c|}{ Content $\left(\mathrm{mg} \mathrm{kg}^{-1}\right)$} & \multicolumn{3}{|c|}{ Uptake $\left(\mathrm{g} \mathrm{ha}^{-1}\right)$} \\
\hline & $2010-11$ & 2011-12 & Pooled & $2010-11$ & $2011-12$ & Pooled & $2010-11$ & $2011-12$ & Pooled & $2010-11$ & 2011-12 & Pooled \\
\hline \multicolumn{13}{|c|}{ Unfertilized treatment } \\
\hline $\mathrm{AC}+\mathrm{MS}_{5}$ & 40.41 & 47.45 & 43.93 & 89.49 & 102.23 & 95.86 & 328.14 & 374.85 & 351.50 & 690.89 & 789.24 & 740.07 \\
\hline $\mathrm{AC}+\mathrm{MS}_{10}$ & 37.45 & 45.14 & 41.30 & 113.95 & 126.84 & 120.40 & 303.17 & 346.33 & 324.75 & 874.34 & 998.80 & 936.57 \\
\hline $\mathrm{AC}+\mathrm{CB}_{5}$ & 38.49 & 44.42 & 41.45 & 96.79 & 110.56 & 103.67 & 319.17 & 364.60 & 341.89 & 759.66 & 867.79 & 813.72 \\
\hline $\mathrm{AC}+\mathrm{CB}_{10}$ & 36.57 & 41.41 & 38.99 & 93.21 & 106.48 & 99.84 & 309.41 & 353.45 & 331.43 & 765.12 & 874.03 & 819.57 \\
\hline $\mathrm{AC}+\mathrm{PJ}_{5}$ & 36.42 & 43.21 & 39.82 & 75.82 & 86.62 & 81.22 & 355.62 & 406.25 & 380.94 & 700.31 & 800.00 & 750.15 \\
\hline $\mathrm{AC}+\mathrm{PJ}_{10}$ & 36.07 & 44.44 & 40.25 & 70.92 & 81.01 & 75.96 & 341.65 & 390.28 & 365.97 & 627.67 & 717.02 & 672.34 \\
\hline $\mathrm{AC}+\mathrm{FYM}_{5}$ & 40.85 & 50.33 & 45.59 & 85.05 & 100.97 & 93.01 & 327.99 & 374.68 & 351.34 & 716.63 & 818.65 & 767.64 \\
\hline $\mathrm{AC}+\mathrm{FYM}_{10}$ & 38.93 & 47.96 & 43.44 & 120.90 & 140.11 & 130.51 & 292.71 & 334.38 & 313.54 & 975.37 & 1114.21 & 1044.79 \\
\hline \multicolumn{13}{|c|}{ Fertilized treatment } \\
\hline $\mathrm{RDF}+\mathrm{MS}_{5}$ & 37.79 & 44.50 & 41.15 & 335.88 & 402.87 & 369.37 & 292.87 & 334.56 & 313.71 & 2388.29 & 2775.71 & 2582.00 \\
\hline $\mathrm{RDF}+\mathrm{MS}_{10}$ & 35.24 & 41.78 & 38.51 & 330.50 & 384.97 & 357.73 & 281.16 & 321.18 & 301.17 & 2321.15 & 2699.01 & 2510.08 \\
\hline $\mathrm{RDF}+\mathrm{CB}_{5}$ & 37.31 & 45.97 & 41.64 & 316.53 & 333.10 & 324.82 & 300.83 & 343.65 & 322.24 & 2196.92 & 2557.10 & 2377.01 \\
\hline $\mathrm{RDF}+\mathrm{CB}_{10}$ & 35.93 & 44.26 & 40.10 & 279.56 & 325.53 & 302.55 & 299.97 & 342.67 & 321.32 & 2211.41 & 2573.65 & 2392.53 \\
\hline $\mathrm{RDF}+\mathrm{PJ}_{5}$ & 41.67 & 51.34 & 46.50 & 207.40 & 251.43 & 229.42 & 315.33 & 413.52 & 364.42 & 1739.47 & 2034.53 & 1887.00 \\
\hline $\mathrm{RDF}+\mathrm{PJ}_{10}$ & 36.02 & 42.32 & 39.17 & 225.70 & 253.07 & 239.38 & 288.29 & 367.41 & 327.85 & 1671.85 & 1957.28 & 1814.56 \\
\hline $\mathrm{RDF}+\mathrm{FYM}_{5}$ & 36.57 & 43.82 & 40.19 & 246.54 & 296.40 & 271.47 & 281.98 & 360.19 & 321.09 & 1827.17 & 2134.72 & 1980.95 \\
\hline $\mathrm{RDF}+\mathrm{FYM}_{10}$ & 40.00 & 44.56 & 42.28 & 320.69 & 270.70 & 295.70 & 285.76 & 364.52 & 325.14 & 2505.23 & 2909.29 & 2707.26 \\
\hline $\mathrm{SEm} \pm$ & 0.78 & 1.12 & 0.68 & 13.86 & 15.08 & 10.24 & 16.66 & 0.64 & 8.34 & 172.39 & 191.41 & 128.80 \\
\hline $\mathrm{CD}(p=0.05)$ & 2.26 & 3.23 & 1.93 & 40.04 & 43.55 & 28.97 & NS & 1.84 & 23.58 & 497.84 & 552.75 & 364.30 \\
\hline \multicolumn{13}{|l|}{$\mathrm{Y}$} \\
\hline SEm \pm & & 0.24 & & & 3.62 & & & 2.94 & & & 128.80 & \\
\hline $\mathrm{CD}(p=0.05)$ & & 0.68 & & & 10.24 & & & 8.33 & & & 364.30 & \\
\hline \multicolumn{13}{|l|}{ YXT } \\
\hline $\mathrm{SEm} \pm$ & & 0.96 & & & 14.48 & & & 11.79 & & & 182.49 & \\
\hline $\mathrm{CD}(p=0.05)$ & & NS & & & NS & & & NS & & & NS & \\
\hline
\end{tabular}

$\mathrm{MS}_{5}$ : Maize stock $\left(5 \mathrm{t} \mathrm{ha}^{-1}\right) ; \mathrm{MS}_{10}$ : Maize stock $\left(10 \mathrm{t} \mathrm{ha}^{-1}\right) ; \mathrm{CB}_{5}$ : Cluster bean $\left(5 \mathrm{t} \mathrm{ha}^{-1}\right) ; \mathrm{CB}_{10}$ : Cluster bean (10 $\left.\mathrm{t} \mathrm{ha}^{-1}\right) ; \mathrm{PJ}_{5}$ : Prosopis julifera wood $\left(\mathrm{PJ}_{5}\right) ; \mathrm{PJ}_{10}$ : Prosopis julifera wood $\left(\mathrm{PJ}_{10}\right) ; \mathrm{FYM}_{5}$ : Farm Yard Manure $\left(5 \mathrm{t} \mathrm{ha}^{-1}\right) ; \mathrm{FYM}_{10}$ : Farm Yard Manure (10 t ha $\left.{ }^{-1}\right)$ 
on Mn concentration of maize plant in both the year (2011 and 2012) as well as pooled basis of both the year. The interaction was found non-significant between year and treatment (Table 4). The application of biochar (MS, CB and PJ) with RDF treatments decreased in Mn concentration of maize plant with increase in the rate of biochar application from $5.0 \mathrm{tha}^{-1}$ to 10.0 tha $^{-1}$. Similar was also true in FYM application. It might be due to higher dry matter production with the higher rate of biochar and FYM. Similar results were also reported by Randon et al. (2007). Application of RDF+MS ${ }_{5}$ (364.36 $\mathrm{g} \mathrm{ha}^{-1}$ ) recorded significantly higher Mn uptake of maize plant followed by $\mathrm{RDF}+\mathrm{MS}_{10}, \mathrm{RDF}+\mathrm{CB}_{10}$ and $\mathrm{RDF}+\mathrm{CB}_{5}$ (Table 3) It indicated that biochar application in presence of fertilized significantly influenced the Mn uptake of maize crop. It might be due to higher dry matter production. Similar types of results are also reported by Major et al. (2006).

\subsubsection{Copper (Cu)}

Application of biochar (MS, CB and PJ) and FYM @ 5 and $10 \mathrm{t}$ with and without fertilized treatments have significant influence on $\mathrm{Cu}$ concentration of maize plant in both the year (2011 and 2012) as well as pooled basis of both the year. The interaction was found non-significant between year and treatment. However, the highest $\mathrm{Cu}$ concentration of maize was observed in treatment of RDF+FYM 5 in year 2011 and 2012 as well as pooled basis (Table 4). The application of biochar (MS, CB and PJ) with and without RDF treatments increased in $\mathrm{Cu}$ concentration of maize plant with increase in the rate of biochar application from $5.0 \mathrm{tha}^{-1}$ to $10.0 \mathrm{tha}^{-1}$. Similar results

\begin{tabular}{|c|c|c|c|c|c|c|c|c|c|c|c|c|}
\hline \multirow[t]{3}{*}{ Treatment } & \multicolumn{6}{|c|}{$\mathrm{Mn}$} & \multicolumn{6}{|c|}{$\mathrm{Cu}$} \\
\hline & \multicolumn{3}{|c|}{ Content $\left(\mathrm{mg} \mathrm{kg}^{-1}\right)$} & \multicolumn{3}{|c|}{ Uptake $\left(\mathrm{g} \mathrm{ha}^{-1}\right)$} & \multicolumn{3}{|c|}{ Content $\left(\mathrm{mg} \mathrm{kg}^{-1}\right)$} & \multicolumn{3}{|c|}{ Uptake $\left(\mathrm{g} \mathrm{ha}^{-1}\right)$} \\
\hline & $2010-11$ & 2011-12 & Pooled & $2010-11$ & 2011-12 & Pooled & $2010-11$ & 2011-12 & Pooled & $2010-11$ & 2011-12 & Pooled \\
\hline \multicolumn{13}{|c|}{ Unfertilized treatment } \\
\hline $\mathrm{AC}+\mathrm{MS}_{5}$ & 37.64 & 42.99 & 40.31 & 80.26 & 93.40 & 86.83 & 4.61 & 5.36 & 4.99 & 11.89 & 13.83 & 12.86 \\
\hline $\mathrm{AC}+\mathrm{MS}_{10}$ & 42.20 & 48.20 & 45.20 & 122.05 & 142.03 & 132.04 & 4.41 & 5.13 & 4.77 & 12.61 & 14.67 & 13.64 \\
\hline $\mathrm{AC}+\mathrm{CB}_{5}$ & 45.09 & 51.51 & 48.30 & 107.25 & 124.81 & 116.03 & 3.84 & 4.47 & 4.15 & 8.49 & 9.88 & 9.18 \\
\hline $\mathrm{AC}+\mathrm{CB}_{10}$ & 45.33 & 51.79 & 48.56 & 113.21 & 131.74 & 122.47 & 4.28 & 4.98 & 4.63 & 8.98 & 10.45 & 9.72 \\
\hline $\mathrm{AC}+\mathrm{PJ}_{5}$ & 34.89 & 39.86 & 37.37 & 66.99 & 77.96 & 72.47 & 3.79 & 4.41 & 4.10 & 7.48 & 8.71 & 8.10 \\
\hline $\mathrm{AC}+\mathrm{PJ}_{10}$ & 43.31 & 49.48 & 46.39 & 78.62 & 91.49 & 85.06 & 3.94 & 4.59 & 4.27 & 7.28 & 8.47 & 7.87 \\
\hline $\mathrm{AC}+\mathrm{FYM}_{5}$ & 38.09 & 43.52 & 40.81 & 77.75 & 90.48 & 84.12 & 4.52 & 5.26 & 4.89 & 9.89 & 11.51 & 10.70 \\
\hline $\mathrm{AC}+\mathrm{FYM}_{10}$ & 37.87 & 43.26 & 40.56 & 114.91 & 133.72 & 124.32 & 4.54 & 5.29 & 4.91 & 15.01 & 17.46 & 16.23 \\
\hline \multicolumn{13}{|c|}{ Fertilized treatment } \\
\hline $\mathrm{RDF}+\mathrm{MS}_{5}$ & 33.43 & 38.66 & 36.05 & 307.95 & 363.82 & 335.88 & 4.47 & 5.26 & 4.87 & 39.18 & 46.14 & 42.66 \\
\hline $\mathrm{RDF}+\mathrm{MS}_{10}$ & 31.21 & 36.13 & 33.67 & 293.16 & 346.61 & 319.88 & 4.66 & 5.48 & 5.07 & 47.90 & 56.29 & 52.10 \\
\hline $\mathrm{RDF}+\mathrm{CB}_{5}$ & 33.25 & 38.46 & 35.86 & 273.48 & 323.71 & 298.59 & 3.91 & 4.60 & 4.26 & 36.49 & 43.01 & 39.75 \\
\hline $\mathrm{RDF}+\mathrm{CB}_{10}$ & 32.92 & 38.08 & 35.50 & 274.16 & 324.50 & 299.33 & 4.63 & 5.44 & 5.04 & 38.77 & 45.66 & 42.22 \\
\hline $\mathrm{RDF}+\mathrm{PJ}_{5}$ & 35.67 & 41.22 & 38.45 & 190.16 & 226.75 & 208.46 & 3.72 & 4.39 & 4.05 & 19.96 & 23.77 & 21.87 \\
\hline $\mathrm{RDF}+\mathrm{PJ}_{10}$ & 33.56 & 38.81 & 36.19 & 196.04 & 233.59 & 214.81 & 4.30 & 5.06 & 4.68 & 25.03 & 29.67 & 27.35 \\
\hline $\mathrm{RDF}+\mathrm{FYM}_{5}$ & 29.79 & 34.50 & 32.14 & 192.81 & 229.83 & 211.32 & 4.69 & 5.51 & 5.10 & 30.98 & 36.59 & 33.79 \\
\hline $\mathrm{RDF}+\mathrm{FYM}_{10}$ & 27.66 & 32.07 & 29.87 & 242.44 & 287.58 & 265.01 & 4.35 & 5.12 & 4.73 & 36.09 & 42.54 & 39.32 \\
\hline $\mathrm{SEm} \pm$ & 1.73 & 1.67 & 1.20 & 17.28 & 20.64 & 13.46 & 0.17 & 0.18 & 0.12 & 39.18 & 46.14 & 42.66 \\
\hline $\mathrm{CD}(p=0.05)$ & 5.00 & 4.82 & 3.40 & 49.89 & 59.61 & 38.07 & 0.50 & 0.52 & 0.35 & 47.90 & 56.29 & 52.10 \\
\hline \multicolumn{13}{|l|}{$\mathrm{Y}$} \\
\hline $\operatorname{SEm} \pm$ & & 0.42 & & & 4.75 & & & 0.04 & & & 0.50 & \\
\hline $\mathrm{CD}(p=0.05)$ & & 1.20 & & & 13.45 & & & 0.12 & & & 1.42 & \\
\hline \multicolumn{13}{|l|}{ YXT } \\
\hline $\operatorname{SEm} \pm$ & & 1.69 & & & 19.03 & & & 0.17 & & & 2.02 & \\
\hline $\mathrm{CD}(p=0.05)$ & & NS & & & NS & & & NS & & & NS & \\
\hline
\end{tabular}

$\mathrm{MS}_{5}$ : Maize stock $\left(5 \mathrm{t} \mathrm{ha}^{-1}\right) ; \mathrm{MS}_{10}$ : Maize stock $\left(10 \mathrm{t} \mathrm{ha}^{-1}\right) ; \mathrm{CB}_{5}$ : Cluster bean $\left(5 \mathrm{t} \mathrm{ha}^{-1}\right) ; \mathrm{CB}_{10}$ : Cluster bean $\left(10 \mathrm{t} \mathrm{ha}^{-1}\right) ; \mathrm{PJ}_{5}$ : Prosopis julifera wood $\left(\mathrm{PJ}_{5}\right) ; \mathrm{PJ}_{10}$ : Prosopis julifera wood $\left(\mathrm{PJ}_{10}\right) ; \mathrm{FYM}_{5}$ : Farm Yard Manure $\left(5 \mathrm{t} \mathrm{ha}^{-1}\right) ; \mathrm{FYM}_{10}$ : Farm Yard Manure (10 t ha $\left.{ }^{-1}\right)$ 
have also been reported by Rondon et al. (2007). Application of $\mathrm{RDF}+\mathrm{MS}_{10}$ recorded significantly higher plant $\mathrm{Cu}$ uptake of maize plant $\left(54.70 \mathrm{~g} \mathrm{ha}^{-1}\right)$. It might be due to 3.27 times higher dry matter production by the $\mathrm{RDF}+\mathrm{MS}_{10}$. It indicated that biochar application in presence of RDF significantly influenced the $\mathrm{Cu}$ uptake of maize crop. It might be due to significantly higher dry matter yield produced by CB biochar in presence of fertilizer and FYM in presence of fertilizer. Similar types of results were also reported by the Major et al. (2010).

\subsection{Available DTPA micronutrient content in soil}

\subsubsection{Zinc (Zn) content}

The result indicated that fertilized biochar treatments $\mathrm{RDF}+\mathrm{MS}_{5}$ and $\mathrm{RDF}+\mathrm{MS}_{10}$ showed $17.39 \%$ and $21.31 \%$ higher DTPA extractable $\mathrm{Zn}$ in soil after harvest of maize crop as compared to $\mathrm{AC}+\mathrm{MS}_{5}$ and $\mathrm{AC}+\mathrm{MS}_{10}$, respectively in both the year (2011 and 2012) as well as pooled basis. The interaction was found non-significant between year and treatment (Table
5). It indicated that biochar application in presence of fertilizer application significantly influenced the DTPA extractable $\mathrm{Zn}$ in soil. Adsorption of the nutrients in clay particles and retaining of the nutrients is increased and prevents it from leaching. Application of increasing rate of maize stover biochar from 5.0 to $10.0 \mathrm{tha}^{-1}$ in presence of fertilizer decreased $\mathrm{Zn}$ content in soil from 1.09 to 1.13 times as compared to same level of biochar in absence of fertilizer. Similar trend was also observed in cluster bean stover biochar and Prosopis julifera wood biochar. This agreement was also supported by Novak et al. (2009) who found that extractable $\mathrm{Zn}$ marginally decreased from 13 to $10 \mathrm{mg} \mathrm{kg}^{-1}$ with an increase in the addition of pecan shell biochar concentration.

\subsubsection{Copper (Cu) content}

The result indicated that there was significant influence of $\mathrm{Cu}$ concentration in soil by the application of fertilized biochar, unfertilized biochar and FYM. However, similar trend was

\begin{tabular}{|c|c|c|c|c|c|c|c|c|c|c|c|c|}
\hline \multirow[b]{3}{*}{ Treatment } & \multirow{2}{*}{\multicolumn{3}{|c|}{$\begin{array}{c}\text { DTPA-Fe } \\
\left(\mathrm{mg} \mathrm{kg}^{-1}\right)\end{array}$}} & \multirow{2}{*}{\multicolumn{3}{|c|}{$\begin{array}{c}\text { DTPA-Mn } \\
\left(\mathrm{mg} \mathrm{kg}^{-1}\right)\end{array}$}} & \multirow{2}{*}{\multicolumn{3}{|c|}{$\begin{array}{r}\text { DTPA-Zn } \\
\left(\mathrm{mg} \mathrm{kg}^{-1}\right)\end{array}$}} & \multirow{2}{*}{\multicolumn{3}{|c|}{$\begin{array}{c}\frac{\text { DTPA-Cu }}{\left(\mathrm{mg} \mathrm{kg}^{-1}\right)}\end{array}$}} \\
\hline & & & & & & & & & & & & \\
\hline & $2010-11$ & $2011-12$ & Pooled & $2010-11$ & $2011-12$ & Pooled & $2010-11$ & $2011-12$ & $\overline{\text { Pooled }}$ & $2010-11$ & $2011-12$ & Pooled \\
\hline \multicolumn{13}{|c|}{ Unfertilized treatment } \\
\hline $\mathrm{AC}+\mathrm{MS}_{5}$ & 7.06 & 8.09 & 7.57 & 13.23 & 15.17 & 14.20 & 1.29 & 1.48 & 1.38 & 1.17 & 1.34 & 1.25 \\
\hline $\mathrm{AC}+\mathrm{MS}_{10}$ & 6.57 & 7.53 & 7.05 & 12.46 & 14.28 & 13.37 & 1.14 & 1.31 & 1.22 & 1.16 & 1.33 & 1.24 \\
\hline $\mathrm{AC}+\mathrm{CB}_{5}$ & 6.91 & 7.92 & 7.41 & 13.46 & 15.43 & 14.44 & 1.20 & 1.38 & 1.29 & 1.00 & 1.14 & 1.07 \\
\hline $\mathrm{AC}+\mathrm{CB}_{10}$ & 6.82 & 7.82 & 7.32 & 13.35 & 15.30 & 14.32 & 1.17 & 1.34 & 1.25 & 0.97 & 1.11 & 1.04 \\
\hline $\mathrm{AC}+\mathrm{PJ}_{5}$ & 6.83 & 7.83 & 7.33 & 13.37 & 15.33 & 14.35 & 1.16 & 1.33 & 1.24 & 0.99 & 1.13 & 1.06 \\
\hline $\mathrm{AC}+\mathrm{PJ}_{10}$ & 6.25 & 7.17 & 6.71 & 12.35 & 14.16 & 13.25 & 1.11 & 1.27 & 1.19 & 0.94 & 1.08 & 1.01 \\
\hline $\mathrm{AC}+\mathrm{FYM}_{5}$ & 6.51 & 7.47 & 6.99 & 12.71 & 14.57 & 13.64 & 1.14 & 1.31 & 1.22 & 0.95 & 1.09 & 1.02 \\
\hline $\mathrm{AC}+\mathrm{FYM}_{10}$ & 7.25 & 8.31 & 7.78 & 13.94 & 15.99 & 14.96 & 1.17 & 1.34 & 1.25 & 1.06 & 1.22 & 1.14 \\
\hline \multicolumn{13}{|c|}{ Fertilized treatment } \\
\hline $\mathrm{RDF}+\mathrm{MS}_{5}$ & 8.99 & 10.50 & 9.75 & 14.69 & 17.04 & 15.87 & 1.58 & 1.80 & 1.69 & 2.26 & 2.44 & 2.35 \\
\hline $\mathrm{RDF}+\mathrm{MS}_{10}$ & 7.99 & 9.36 & 8.67 & 18.46 & 20.77 & 19.61 & 1.45 & 1.65 & 1.55 & 2.21 & 2.37 & 2.29 \\
\hline $\mathrm{RDF}+\mathrm{CB}_{5}$ & 7.25 & 8.51 & 7.88 & 18.37 & 20.67 & 19.52 & 1.35 & 1.54 & 1.45 & 2.07 & 2.21 & 2.14 \\
\hline $\mathrm{RDF}+\mathrm{CB}_{10}$ & 7.02 & 8.24 & 7.63 & 17.16 & 19.28 & 18.22 & 1.29 & 1.47 & 1.38 & 2.17 & 2.33 & 2.25 \\
\hline $\mathrm{RDF}+\mathrm{PJ}_{5}$ & 6.41 & 7.55 & 6.98 & 17.50 & 19.67 & 18.58 & 1.27 & 1.45 & 1.36 & 2.21 & 2.37 & 2.29 \\
\hline $\mathrm{RDF}+\mathrm{PJ}_{10}^{3}$ & 6.38 & 7.50 & 6.94 & 16.61 & 18.65 & 17.63 & 1.25 & 1.43 & 1.34 & 2.16 & 2.32 & 2.24 \\
\hline $\mathrm{RDF}+\mathrm{FYM}_{5}$ & 6.04 & 7.12 & 6.58 & 17.30 & 19.44 & 18.37 & 1.26 & 1.44 & 1.35 & 2.21 & 2.37 & 2.29 \\
\hline $\mathrm{RDF}+\mathrm{FYM}_{10}$ & 6.29 & 7.41 & 6.85 & 17.53 & 19.70 & 18.61 & 1.32 & 1.50 & 1.41 & 2.21 & 2.38 & 2.30 \\
\hline $\mathrm{SEm} \pm$ & 0.33 & 0.32 & 0.23 & 0.32 & 0.32 & 0.23 & 0.03 & 0.03 & 0.02 & 0.03 & 0.03 & 0.02 \\
\hline $\mathrm{CD}(p=0.05)$ & 0.94 & 0.93 & 0.65 & 0.93 & 0.92 & 0.64 & 0.10 & 0.10 & 0.07 & 0.10 & 0.10 & 0.07 \\
\hline \multicolumn{13}{|l|}{ Y } \\
\hline$\overline{\mathrm{SE}} \mathrm{m} \pm$ & & 0.08 & & & 0.08 & & & 0.008 & & & 0.008 & \\
\hline $\mathrm{CD}(p=0.05)$ & & 0.22 & & & 0.22 & & & 0.023 & & & 0.023 & \\
\hline \multicolumn{13}{|l|}{ YXT } \\
\hline $\mathrm{SEm} \pm$ & & 0.32 & & & 0.32 & & & 0.03 & & & 0.033 & \\
\hline $\mathrm{CD}(p=0.05)$ & & NS & & & NS & & & NS & & & NS & \\
\hline
\end{tabular}


also observed in case of $\mathrm{Cu}$ like $\mathrm{Zn}$ in both the year (2011 and 2012) as well as pooled basis. The interaction was found nonsignificant between year and treatment (Table 5). The similar types of results were also reported by the Novak et al. (2009) and they indicated that the copper $(\mathrm{Cu})$ concentration of soil was not significantly affected by the biochar addition.

\subsubsection{Manganese (Mn) content}

The result indicated that application of $\mathrm{RDF}+\mathrm{MS}_{5}$ recorded significantly higher DTPA extractable Mn in soil $(17.17 \mathrm{mg}$ $\mathrm{kg}^{-1}$ ) after harvest of maize crop than $\mathrm{AC}+\mathrm{MS}_{5}, \mathrm{AC}+\mathrm{MS}_{10}$, $\mathrm{AC}+\mathrm{CB}_{5}, \mathrm{AC}+\mathrm{CB}_{10}, \mathrm{AC}+\mathrm{PJ}_{5}, \mathrm{AC}+\mathrm{PJ}_{10}$ and $\mathrm{AC}+\mathrm{FYM}_{5}$. The combined application of RDF with maize stover biochar, cluster bean stover biochar, Prosopis julifera wood biochar and FYM gave 1.24, 1.13, 1.12 and 1.11 times higher Mn concentration in soil over unfertilized application of corresponding biochar and FYM, respectively after 60 days of the maize crop growth in both the year (2011 and 2012) as well as pooled basis. The interaction was found non-significant between year and treatment (Table 5). Novak et al. (2009) found that in pecan shell based biochar; the soil had increased Mn concentrations after the 67 day trial period. This demonstrates that Mn was largely retained during biochar formation due to its high association with a number of organic and inorganic forms in the biomass (Amonette and Joseph, 2009).

\subsubsection{Iron $(\mathrm{Fe})$ content}

It was indicated that available $\mathrm{Fe}$ content in soil increased significantly by the application of fertilized maize stover biochar. Application of $\mathrm{RDF}+\mathrm{MS}_{5}$ recorded significantly higher DTPA extractable Fe in soil (11.06 $\left.\mathrm{mg} \mathrm{kg}^{-1}\right)$ after harvest of maize crop than other treatments but it was at par with $\mathrm{RDF}+\mathrm{MS}_{10}\left(9.99 \mathrm{mg} \mathrm{kg}^{-1}\right)$ in both the year (2011 and 2012) as well as pooled basis. The interaction was found nonsignificant between year and treatment (Table 5). Further, the result indicated that fertilized biochar treatments $\mathrm{RDF}+\mathrm{MS}_{5}$, $\mathrm{RDF}+\mathrm{MS}_{10}$ and $\mathrm{RDF}+\mathrm{CB}_{5}$ were highly effective in increasing DTPA extractable Fe in soil by $46.29 \%, 41.90 \%$ and $24.32 \%$ as compared to $\mathrm{AC}+\mathrm{MS}_{5}, \mathrm{AC}+\mathrm{MS}_{10}$ and $\mathrm{AC}+\mathrm{CB}_{5}$, respectively. Results indicated that biochar application in presence of fertilized treatments significantly influenced the available Fe in soil. The above result indicated that maize stover biochar with $\mathrm{RDF}\left(\mathrm{RDF}+\mathrm{MS}_{5}\right)$ retain more Fe content in soil as compared to other type of biochar, that is $\left(11.06 \mathrm{mg} \mathrm{kg}^{-1}\right)$ and minimum Fe concentration $\left(8.26 \mathrm{mg} \mathrm{kg}^{-1}\right)$ was in $\mathrm{RDF}+\mathrm{PJ}_{10}$. The maize stover biochar showed its superiority over the other type of biochar and it also retained $\mathrm{Fe}$ and $\mathrm{Mn}$ concentration. Amonette and Joseph (2009) also found that Fe and $\mathrm{Mn}$ are associated, and largely retained during biochar formation. Similar type of results also found that poultry litter biochar had the highest amount of Fe compared to peanut hulls and pine chips (Gaskin et al., 2008).

\section{3. $\mathrm{Ca}, \mathrm{Mg}$ and $\mathrm{S}$ content and uptake in plant}

\subsubsection{Calcium (Ca)}

Application of $\mathrm{RDF}+\mathrm{PJ}_{5}$ recorded significantly higher plant $\mathrm{Ca}$ concentration $(0.513 \%)$ followed by $\mathrm{RDF}+\mathrm{FYM}_{5}, \mathrm{RDF}+\mathrm{PJ}_{10}$, $\mathrm{RDF}+\mathrm{MS}_{10}, \mathrm{RDF}+\mathrm{CB}_{10}, \mathrm{RDF}+\mathrm{MS}_{5}, \mathrm{AC}+\mathrm{PJ}_{10}, \mathrm{AC}+\mathrm{FYM} \mathrm{M}_{5}$, $\mathrm{AC}+\mathrm{FYM}_{10}, \mathrm{AC}+\mathrm{CB}_{5}$ and $\mathrm{AC}+\mathrm{MS}_{5}($ Table 7 and 8$)$. Similar results were also reported by Gaskin et al. (2010). Application of $\mathrm{RDF}+\mathrm{MS}_{10}\left(46.02 \mathrm{~kg} \mathrm{ha}^{-1}\right)$ recorded significantly higher plant $\mathrm{Ca}$ uptake followed by $\mathrm{RDF}+\mathrm{MS}_{5}$. The results clearly indicate that application of biochar in presence RDF treatment positively influenced the Ca uptake of maize crop in both the year (2011 and 2012) as well as pooled basis. The interaction was found non-significant between year and treatment. The magnitude of Ca uptake increased to the tune of three to four folds as compared to unfertilized biochar. Similar was also true for FYM treatments. It might be due to significantly higher dry matter yield obtained with fertilized biochar treatments. Results indicated that there was a positive significant correlation $\left(\mathrm{r}=0.986^{* *}\right)$ with an increase in rate of biochar and fertilized treatments of Ca uptake and dry matter yield of maize plant. Positive effect of biochar application on crop growth, yield and uptake (radish and common bean) has also been reported by several workers (Chan et al., 2007; Asai et al., 2009).

\subsubsection{Magnesium (Mg)}

Application of $\mathrm{RDF}+\mathrm{CB}_{5}$ recorded significantly higher $\mathrm{Mg}$ concentration of maize plant $(0.43 \%)$ followed by $\mathrm{RDF}+\mathrm{CB}_{10}$, $\mathrm{RDF}+\mathrm{PJ}_{10}, \mathrm{RDF}+\mathrm{MS}_{10}, \mathrm{RDF}+\mathrm{PJ}_{5}$ and $\mathrm{RDF}+\mathrm{MS}_{5}$. It showed that fertilized biochar application significantly influenced the Mg concentration of maize plant in both the year (2011 and 2012) as well as pooled basis. The interaction was found non-significant between year and treatment (Table 7 and 8). Similar results were also obtained by Uzoma et al. (2011). The further results indicate that application of $\mathrm{RDF}+\mathrm{MS}_{10}$ recorded significantly higher plant $\mathrm{Mg}$ uptake (37.34 $\left.\mathrm{kg} \mathrm{ha}^{-1}\right)$ followed by $\mathrm{RDF}+\mathrm{CB}_{5}, \mathrm{RDF}+\mathrm{MS}_{5}$ and $\mathrm{RDF}+\mathrm{CB}_{10}$. The results clearly indicate that biochar application in presence of fertilizer significantly influenced the Mg uptake of maize crop. It might be due to higher dry matter production. Results indicated that there was a highly positive significantly correlation $\left(\mathrm{r}=0.957^{* *}\right)$ with an increase in the rate of biochar and fertilized treatments of $\mathrm{Mg}$ uptake and dry matter yield of maize plant. Similar results have also been reported by Chan et al. (2008).

\subsubsection{Sulphur (S)}

Application of $\mathrm{AC}+\mathrm{CB}_{5}$ recorded significantly higher plant $\mathrm{S}$ 
concentration $(0.340 \%)$ followed by $\mathrm{RDF}+\mathrm{CB}_{5}, \mathrm{RDF}+\mathrm{CB}_{10}$, $\mathrm{AC}+\mathrm{FYM}, \mathrm{RDF}+\mathrm{PJ}_{5}, \mathrm{RDF}+\mathrm{MS}_{10}, \mathrm{AC}+\mathrm{PJ}_{10}, \mathrm{AC}+\mathrm{CB}_{10}$, $\mathrm{RDF}+\mathrm{MS}_{5}, \mathrm{AC}+\mathrm{MS}_{10}$ and $\mathrm{AC}+\mathrm{MS}_{5}$ (Chan et al., 2008). Application of $\mathrm{RDF}+\mathrm{MS}_{10}$ recorded significantly higher plant $\mathrm{S}$ uptake $\left(30.21 \mathrm{~kg} \mathrm{ha}^{-1}\right)$ followed by $\mathrm{RDF}+\mathrm{CB}_{10}, \mathrm{RDF}+\mathrm{MS}_{5}$ and $\mathrm{RDF}+\mathrm{CB}_{5}$. It indicated that biochar application in presence of fertilizer significantly influenced the $\mathrm{S}$ uptake of maize crop in both the year (2011 and 2012) as well as pooled basis. The interaction was found non-significant between year and treatment (Table 7 and 8). It might be due to higher dry matter yield. In presence of fertilized, MS and CB biochar showed more effectiveness in increasing $\mathrm{S}$ uptake of maize shoot as compared to PJ biochar and FYM. In absence of fertilizer, all the type of biochars and FYM failed to show its superiority might be due to low soil fertility status of the experimental soil $\left(8.2 \mathrm{mg} \mathrm{kg}^{-1}\right)$. Thereby lower production of dry matter yield. The results indicated that there was a positive significant correlation $\left(\mathrm{r}=0.977^{* *}\right)$ with an increase in rate of biochar and fertilized treatments of S uptake and dry matter yield of maize plants (Chan et al., 2008).

\subsection{Available Ca, $\mathrm{Mg}$, and $\mathrm{S}$ content in soil}

\subsubsection{Calcium (Ca)}

The data depicted in (Table 8) indicated that application of $\mathrm{RDF}+\mathrm{MS}_{10}$ recorded significantly higher available $\mathrm{Ca}$ in soil (1180 ppm) after harvest of maize crop than other treatments. Results indicated that biochar application in presence of fertilized treatments significantly influenced the available $\mathrm{Ca}$ in soil in both the year (2011 and 2012) as well as pooled basis. The interaction was found non-significant between year and treatment. Similar type of results also found that application of biochar increased the Ca concentration in a study conducted on the response of DM production of radish using green-waste (Chan et al., 2007). There was a significant increase in biochar application rate greater than $50 \mathrm{t} \mathrm{ha}^{-1}$ and when no $\mathrm{N}$ fertilizer was applied and also Adekayode and Olojugba (2010) reported

\begin{tabular}{|c|c|c|c|c|c|c|c|c|c|}
\hline \multirow[t]{2}{*}{ Treatment } & \multicolumn{3}{|c|}{$\mathrm{Ca}\left(\mathrm{mg} \mathrm{kg}^{-1}\right)$} & \multicolumn{3}{|c|}{$\mathrm{Mg}\left(\mathrm{mg} \mathrm{kg}^{-1}\right)$} & \multicolumn{3}{|c|}{$\mathrm{S}\left(\mathrm{mg} \mathrm{kg}^{-1}\right)$} \\
\hline & $2010-11$ & 2011-12 & Pooled & $2010-11$ & 2011-12 & Pooled & $2010-11$ & 2011-12 & Pooled \\
\hline \multicolumn{10}{|c|}{ Unfertilized treatment } \\
\hline $\mathrm{AC}+\mathrm{MS}_{5}$ & 0.40 & 0.46 & 0.43 & 0.30 & 0.34 & 0.32 & 0.27 & 0.31 & 0.29 \\
\hline $\mathrm{AC}+\mathrm{MS}_{10}$ & 0.38 & 0.44 & 0.41 & 0.22 & 0.26 & 0.24 & 0.28 & 0.32 & 0.30 \\
\hline $\mathrm{AC}+\mathrm{CB}_{5}$ & 0.41 & 0.47 & 0.44 & 0.23 & 0.27 & 0.25 & 0.32 & 0.36 & 0.34 \\
\hline $\mathrm{AC}+\mathrm{CB}_{10}$ & 0.36 & 0.42 & 0.39 & 0.21 & 0.24 & 0.22 & 0.29 & 0.33 & 0.31 \\
\hline $\mathrm{AC}+\mathrm{PJ}_{5}$ & 0.33 & 0.37 & 0.35 & 0.22 & 0.26 & 0.24 & 0.21 & 0.25 & 0.23 \\
\hline $\mathrm{AC}+\mathrm{PJ}_{10}$ & 0.46 & 0.52 & 0.49 & 0.29 & 0.33 & 0.31 & 0.29 & 0.33 & 0.31 \\
\hline $\mathrm{AC}+\mathrm{FYM}_{5}$ & 0.43 & 0.49 & 0.46 & 0.28 & 0.32 & 0.30 & 0.31 & 0.35 & 0.33 \\
\hline $\mathrm{AC}+\mathrm{FYM}_{10}$ & 0.42 & 0.48 & 0.45 & 0.30 & 0.34 & 0.32 & 0.23 & 0.27 & 0.25 \\
\hline \multicolumn{10}{|c|}{ Fertilized treatment } \\
\hline $\mathrm{RDF}+\mathrm{MS}_{5}$ & 0.71 & 0.77 & 0.74 & 0.59 & 0.64 & 0.61 & 0.55 & 0.59 & 0.57 \\
\hline $\mathrm{RDF}+\mathrm{MS}_{10}$ & 0.71 & 0.78 & 0.75 & 0.61 & 0.66 & 0.63 & 0.57 & 0.61 & 0.59 \\
\hline $\mathrm{RDF}+\mathrm{CB}_{5}$ & 0.71 & 0.78 & 0.75 & 0.63 & 0.69 & 0.66 & 0.57 & 0.62 & 0.60 \\
\hline $\mathrm{RDF}+\mathrm{CB}_{10}$ & 0.71 & 0.77 & 0.74 & 0.63 & 0.68 & 0.65 & 0.57 & 0.62 & 0.60 \\
\hline $\mathrm{RDF}+\mathrm{PJ}_{5}$ & 0.74 & 0.81 & 0.78 & 0.60 & 0.65 & 0.62 & 0.57 & 0.61 & 0.59 \\
\hline $\mathrm{RDF}+\mathrm{PJ}_{10}$ & 0.72 & 0.79 & 0.76 & 0.61 & 0.66 & 0.63 & 0.54 & 0.58 & 0.56 \\
\hline $\mathrm{RDF}+\mathrm{FYM}_{5}$ & 0.72 & 0.79 & 0.76 & 0.53 & 0.58 & 0.55 & 0.48 & 0.51 & 0.50 \\
\hline $\mathrm{RDF}+\mathrm{FYM}_{10}$ & 0.65 & 0.71 & 0.68 & 0.54 & 0.59 & 0.56 & 0.49 & 0.52 & 0.51 \\
\hline $\mathrm{SEm} \pm$ & 0.03 & 0.03 & 0.02 & 0.02 & 0.02 & 0.01 & 0.03 & 0.03 & 0.02 \\
\hline $\mathrm{CD}(p=0.05)$ & 0.10 & 0.10 & 0.07 & 0.05 & 0.05 & 0.03 & 0.10 & 0.10 & 0.07 \\
\hline \multicolumn{10}{|l|}{$\mathrm{Y}$} \\
\hline$\overline{\mathrm{SE}} \mathrm{m} \pm$ & & 0.008 & & & 0.004 & & & 0.008 & \\
\hline $\mathrm{CD}(p=0.05)$ & & 0.02 & & & 0.011 & & & 0.024 & \\
\hline \multicolumn{10}{|l|}{ YXT } \\
\hline $\mathrm{SEm} \pm$ & & 0.03 & & & 0.016 & & & 0.034 & \\
\hline $\mathrm{CD}(p=0.05)$ & & NS & & & NS & & & NS & \\
\hline
\end{tabular}


Table 7: Secondary nutrient uptake influence by different treatment of biochar in maize plant (pooled data of two year)

\begin{tabular}{|c|c|c|c|c|c|c|c|c|c|}
\hline \multirow[t]{3}{*}{ Treatment } & \multicolumn{3}{|c|}{$\mathrm{Ca}$} & \multicolumn{3}{|c|}{$\mathrm{Mg}$} & \multicolumn{3}{|c|}{$\mathrm{S}$} \\
\hline & \multicolumn{3}{|c|}{$\left(\mathrm{g} \mathrm{ha}^{-1}\right)$} & \multicolumn{3}{|c|}{$\left(\mathrm{g} \mathrm{ha}^{-1}\right)$} & \multicolumn{3}{|c|}{$\left(\mathrm{g} \mathrm{ha}^{-1}\right)$} \\
\hline & 2010-11 & 2011-12 & Pooled & $2010-11$ & 2011-12 & Pooled & $2010-11$ & $2011-12$ & Pooled \\
\hline \multicolumn{10}{|c|}{ Unfertilized treatment } \\
\hline $\mathrm{AC}+\mathrm{MS}_{5}$ & 8.63 & 9.90 & 9.27 & 6.22 & 7.13 & 6.67 & 5.81 & 6.66 & 6.23 \\
\hline $\mathrm{AC}+\mathrm{MS}_{10}$ & 11.17 & 12.81 & 11.99 & 6.54 & 7.50 & 7.02 & 8.11 & 9.30 & 8.70 \\
\hline $\mathrm{AC}+\mathrm{CB}_{5}$ & 9.89 & 11.34 & 10.62 & 5.45 & 6.25 & 5.85 & 7.55 & 8.66 & 8.10 \\
\hline $\mathrm{AC}+\mathrm{CB}_{10}$ & 9.02 & 10.34 & 9.68 & 5.11 & 5.85 & 5.48 & 7.11 & 8.15 & 7.63 \\
\hline $\mathrm{AC}+\mathrm{PJ}_{5}$ & 6.25 & 7.17 & 6.71 & 4.19 & 4.80 & 4.50 & 4.06 & 4.65 & 4.36 \\
\hline $\mathrm{AC}+\mathrm{PJ}_{10}$ & 8.43 & 9.66 & 9.05 & 5.25 & 6.01 & 5.63 & 5.47 & 6.27 & 5.87 \\
\hline $\mathrm{AC}+\mathrm{FYM}_{5}$ & 8.84 & 10.13 & 9.49 & 5.71 & 6.55 & 6.13 & 6.36 & 7.29 & 6.82 \\
\hline $\mathrm{AC}+\mathrm{FYM}_{10}$ & 12.95 & 14.85 & 13.90 & 9.17 & 10.51 & 9.84 & 7.23 & 8.29 & 7.76 \\
\hline \multicolumn{10}{|c|}{ Fertilized treatment } \\
\hline $\mathrm{RDF}+\mathrm{MS}_{5}$ & 39.59 & 43.66 & 41.62 & 32.69 & 36.87 & 34.78 & 26.55 & 27.85 & 27.20 \\
\hline $\mathrm{RDF}+\mathrm{MS}_{10}$ & 41.82 & 46.11 & 43.97 & 34.38 & 38.82 & 36.60 & 28.40 & 29.88 & 29.14 \\
\hline $\mathrm{RDF}+\mathrm{CB}_{5}$ & 36.35 & 40.10 & 38.22 & 33.11 & 37.37 & 35.24 & 26.33 & 27.61 & 26.97 \\
\hline $\mathrm{RDF}+\mathrm{CB}_{10}$ & 36.50 & 40.26 & 38.38 & 32.41 & 36.55 & 34.48 & 26.86 & 28.19 & 27.52 \\
\hline $\mathrm{RDF}+\mathrm{PJ}_{5}$ & 26.49 & 29.26 & 27.87 & 20.74 & 23.18 & 21.96 & 17.52 & 17.92 & 17.72 \\
\hline $\mathrm{RDF}+\mathrm{PJ}_{10}$ & 27.19 & 30.03 & 28.61 & 22.69 & 25.41 & 24.05 & 16.97 & 17.32 & 17.14 \\
\hline $\mathrm{RDF}+\mathrm{FYM}_{5}$ & 30.40 & 33.56 & 31.98 & 20.16 & 22.51 & 21.34 & 14.97 & 15.12 & 15.05 \\
\hline $\mathrm{RDF}+\mathrm{FYM}_{10}$ & 33.60 & 37.07 & 35.33 & 27.18 & 30.56 & 28.87 & 20.31 & 20.99 & 20.65 \\
\hline $\operatorname{SEm} \pm$ & 1.01 & 1.92 & 1.08 & 0.63 & 1.02 & 0.60 & 0.22 & 1.46 & 0.74 \\
\hline $\mathrm{CD}(p=0.05)$ & 2.92 & 5.54 & 3.07 & 1.82 & 2.95 & 1.70 & 0.64 & 4.23 & 2.09 \\
\hline \multicolumn{10}{|l|}{$\mathrm{Y}$} \\
\hline$\overline{\mathrm{SEm}} \pm$ & & 0.3834 & & & 0.21 & & & 0.26 & \\
\hline $\mathrm{CD}(p=0.05)$ & & 1.0845 & & & 0.60 & & & 0.74 & \\
\hline \multicolumn{10}{|l|}{ YXT } \\
\hline $\mathrm{SEm} \pm$ & & 1.5337 & & & 0.85 & & & 1.04 & \\
\hline $\mathrm{CD}(p=0.05)$ & & NS & & & NS & & & NS & \\
\hline
\end{tabular}

that application of wood ash at 2 tons per hectare along with $\mathrm{RDF}\left(200 \mathrm{~kg} \mathrm{ha}^{-1}\right)$ significantly higher $\mathrm{Ca}\left(3.26 \mathrm{C} \mathrm{mol} \mathrm{ha}^{-1}\right)$ in maize crop compared to alone wood ash treatments.

\subsubsection{Magnesium (Mg)}

The available $\mathrm{Mg}$ content of soil showed a significant alteration by fertilized maize stover biochar, where in RDF+MS ${ }_{10}(1127$ ppm), recorded maximum available $\mathrm{Mg}$ in soil after harvest of maize crop than other treatments in both the year (2011 and 2012) as well as pooled basis. The interaction was found non-significant between year and treatment (Table 8). Results indicated that biochar application in presence of fertilizer significantly influenced the available $\mathrm{Mg}$ in soil. Similar type of results were also reported by Major et al. (2010) who found that the available $\mathrm{Mg}$ content increased from $64 \%$ to $217 \%$ over a biochar application rate from 0-20 $\mathrm{tha}^{-1}$.

3.4.3. S content in soil
The result indicated that application of $\mathrm{RDF}+\mathrm{CB}_{10}$ recorded significantly higher available $\mathrm{S}\left(16.35 \mathrm{mg} \mathrm{kg}^{-1}\right)$ in soil after harvest of maize crop than other treatments in both the year (2011 and 2012) as well as pooled basis. The interaction was found non-significant between year and treatment (Table 8). Further, the result indicated that fertilized biochar treatments $\mathrm{RDF}+\mathrm{CB}_{10}, \mathrm{RDF}+\mathrm{PJ}_{10}, \mathrm{RDF}+\mathrm{MS}_{10}$ and $\mathrm{RDF}+\mathrm{CB}_{5}$ showed its superiority ranging from $3.94 \%$ to $21.20 \%$ higher available $\mathrm{S}$ in soil after harvest of maize crop as compared to unfertilized biochar treatments. It indicated that biochar application in presence of fertilized soil significantly influenced the available $\mathrm{S}$ in soil. Similar type results also reported by Novak et al. (2009) who found that application of pecan shell biochar @ $0.5 \%, 1.0 \%$ and $2 \%$ along with fertilizer significantly increased sulphur content with an increase in biochar concentration that was added. 


\begin{tabular}{|c|c|c|c|c|c|c|c|c|c|}
\hline \multirow[t]{3}{*}{ Treatment } & \multicolumn{3}{|c|}{$\mathrm{Ca}$} & \multicolumn{3}{|c|}{$\mathrm{Mg}$} & \multicolumn{3}{|c|}{$\mathrm{S}$} \\
\hline & \multicolumn{3}{|c|}{$\left(\mathrm{mg} \mathrm{kg}^{-1}\right)$} & \multicolumn{3}{|c|}{$\left(\mathrm{mg} \mathrm{kg}^{-1}\right)$} & \multicolumn{3}{|c|}{$\left(\mathrm{mg} \mathrm{kg}^{-1}\right)$} \\
\hline & $2010-11$ & 2011-12 & Pooled & $2010-11$ & 2011-12 & Pooled & $2010-11$ & $2011-12$ & Pooled \\
\hline \multicolumn{10}{|c|}{ Unfertilized treatment } \\
\hline $\mathrm{AC}+\mathrm{MS}_{5}$ & 827.87 & 949.09 & 888.48 & 719.87 & 863.49 & 791.68 & 10.19 & 12.06 & 11.12 \\
\hline $\mathrm{AC}+\mathrm{MS}_{10}$ & 865.20 & 991.89 & 928.55 & 825.33 & 917.73 & 871.53 & 9.45 & 10.83 & 10.14 \\
\hline $\mathrm{AC}+\mathrm{CB}_{5}$ & 840.00 & 963.00 & 901.50 & 775.87 & 927.69 & 851.78 & 12.27 & 14.07 & 13.17 \\
\hline $\mathrm{AC}+\mathrm{CB}_{10}$ & 858.67 & 984.40 & 921.53 & 806.67 & 963.00 & 884.83 & 12.35 & 14.83 & 13.59 \\
\hline $\mathrm{AC}+\mathrm{PJ}_{5}$ & 865.20 & 991.89 & 928.55 & 781.47 & 934.11 & 857.79 & 12.44 & 12.93 & 12.69 \\
\hline $\mathrm{AC}+\mathrm{PJ}_{10}$ & 896.00 & 1027.20 & 961.60 & 769.33 & 920.20 & 844.77 & 12.03 & 14.18 & 13.11 \\
\hline $\mathrm{AC}+\mathrm{FYM}_{5}$ & 858.67 & 984.40 & 921.53 & 797.33 & 952.30 & 874.82 & 9.77 & 11.20 & 10.49 \\
\hline $\mathrm{AC}+\mathrm{FYM}_{10}$ & 914.67 & 1048.60 & 981.63 & 862.67 & 1027.20 & 944.93 & 12.95 & 11.94 & 12.45 \\
\hline \multicolumn{10}{|c|}{ Fertilized treatment } \\
\hline $\mathrm{RDF}+\mathrm{MS}_{5}$ & 1084.33 & 1199.73 & 1142.03 & 1017.53 & 1133.17 & 1075.35 & 11.99 & 13.71 & 12.85 \\
\hline $\mathrm{RDF}+\mathrm{MS}_{10}$ & 1070.67 & 1221.13 & 1145.90 & 1052.07 & 1172.76 & 1112.41 & 13.63 & 15.60 & 14.61 \\
\hline $\mathrm{RDF}+\mathrm{CB}_{5}$ & 1032.54 & 1202.20 & 1117.37 & 1040.33 & 1049.54 & 1044.94 & 13.51 & 15.46 & 14.48 \\
\hline $\mathrm{RDF}+\mathrm{CB}_{10}$ & 1005.46 & 1204.18 & 1104.82 & 1056.20 & 1067.73 & 1061.97 & 12.46 & 15.69 & 14.08 \\
\hline $\mathrm{RDF}+\mathrm{PJ}_{5}$ & 969.13 & 1081.29 & 1025.21 & 933.67 & 989.04 & 961.36 & 12.98 & 14.85 & 13.91 \\
\hline $\mathrm{RDF}+\mathrm{PJ}_{10}$ & 1006.70 & 1112.16 & 1059.43 & 1006.73 & 977.69 & 992.21 & 13.86 & 17.38 & 15.62 \\
\hline $\mathrm{RDF}+\mathrm{FYM}_{5}$ & 1017.26 & 1082.03 & 1049.65 & 1021.67 & 1028.14 & 1024.91 & 11.99 & 13.71 & 12.85 \\
\hline $\mathrm{RDF}+\mathrm{FYM}_{10}$ & 1033.73 & 1110.92 & 1072.33 & 1046.87 & 1057.03 & 1051.95 & 13.67 & 16.79 & 15.23 \\
\hline $\operatorname{SEm} \pm$ & 22.91 & 28.33 & 18.22 & 35.26 & 42.05 & 27.44 & 0.71 & 0.93 & 0.58 \\
\hline $\mathrm{CD}(p=0.05)$ & 66.16 & 81.81 & 51.53 & 101.83 & 121.42 & 77.60 & 2.04 & 2.68 & 1.65 \\
\hline \multicolumn{10}{|l|}{$\mathrm{Y}$} \\
\hline$\overline{\mathrm{SEm}} \pm$ & & 6.44 & & & 9.70 & & & 0.20 & \\
\hline $\mathrm{CD}(p=0.05)$ & & 18.21 & & & 27.43 & & & 0.58 & \\
\hline \multicolumn{10}{|l|}{ YXT } \\
\hline $\operatorname{SEm} \pm$ & & 25.76 & & & 38.80 & & & 0.82 & \\
\hline $\mathrm{CD}(p=0.05)$ & & NS & & & NS & & & NS & \\
\hline
\end{tabular}

\section{Conclusion}

Biochar can be suitably used as an alternative source of organic manure in case of non-availability of FYM. All the organic sources have been found to improve the secondary and micro nutrient content as compared to initial soil nutrient status. The uptake of secondary and micronutrient was found to be higher when biochar was applied along with RDF as compared to sole application of biochar and ultimately improve secondary and micronutrient status in the soil which have direct role in soil fertilization.

\section{References}

Adekayode, F.O., Olojugba, M.R., 2010. The utilization of wood ash as manure to reduce the use of mineral fertilizer for improved performance of maize (Zea mays L.) as measured in the chlorophyll content and grain yield. Journal of Soil Science and Environmental Management
$1(2), 40-45$.

Amonette, J.E., Joseph, S., 2009. Characteristics of biochar: Microchemical properties. In: Lehmann, J., Joseph, S. (Eds.), Biochar for environmental management: science and technology, Earthscan London; Sterling, VA, 3352.

Asai, H., Samson, B.K., Stephan, H.M., Songyikhangsuthor, K., Homma, K., Kiyono, Y., Inoue, Y., Shiraiwa, T., Horie, T., 2009. Biochar amendment techniques for upland production in Northern laso 1. Soil physical properties, leaf SPAD and grain yield. Field Crop Research 111, 81-84.

Chan, K.Y., Van Zwieten, L., Meszaros, I., Downie, A., Joseph, S., 2007. Agronomic valuses of greenwastebiochar as a soil amendment. Australian Journal Soil Research 45, 629-634.

Chan, K.Y., Van Zwieten, L., Meszaros, I., Downie, A., Joseph, S., 2008. Using poultry litter biochars as soil amendments. 
Australian Journal Soil Research 46, 437-444.

Cheng, A.C., Bray, R.H., 1951. Determination of calcium and magnesium in soil and plant materials. Soil Science 72, 449-458.

Gaskin, J.W., Steiner, C., Harris, K., Das, K.C., Biben, B., 2008. Effect of low-temperature pyrolysis conditions on biochar for agricultural use. Transactions of the ASABE 51, 2061-2069.

Glaser, B., Lehmann, J., Zech, W., 2002. Ameliorating physical and chemical properties of highly weathered soils in the tropics with charcoal-a review. Biology and fertility of soils $35,219-230$.

Iswaran, V., Jauhri, K.S., Sen, A., 1980. Effect of Charcoal, Coal and Peat on the Yield of Moong, Soybean and Pea. Soil Biology and Biochemistry 12,191-192.

Jackson, M.L., 1973. Soil Chemical Analysis. Prentice Hall of India Pvt. Ltd., New Delhi.

Lehmann, J., Silva, D., Jr, J.P., Steiner, C., Nehls, T., Zech, W., Glaser, B., 2003. Nutrient availability and leaching in an archaeological Anthrosol and a Ferralsol of the central Amazon Basin: fertilizer, manure and charcoal amendments. Plant and Soil 249, 343-357.

Lindsay, W.L., Norvell, W.A., 1978. Development of a DTPA soil test for zinc, iron, manganese and copper. Soil Science Society of America Journal 42(3), 421-442.

Major, J., Lehman, J., Rondon, M., 2006. Biochar application to a tropical oxisol modifies water relations. Poster at the World Soil Congress. Philadelphia, PA.

Major, J., Rondon, M., Molina, D., Rinha, S.J., Lehman,
J., 2010. Maize yield and nutrition during 4 year after biochar application to a Colombian savannaoxisol. Plant and Soil 333, 117-128.

Novak, J.M., Busscher, W.J., Laird, D.L., Ahmendna, M., Watts, D.W., Niandou, M.A.S., 2009. Impact of biochar amendment on fertility of a southeastern coastal plain soil. Soil Science 174(2), 105-112.

Rondon, M.A., Lehmann, J., Ramirez, J., Hurtado, M., 2007. Biological nitrogen fixation by common beans (Phaseolus vulgaris L.) increases with biochar additions. Biologyand fertility of Soils 43, 699-708.

Rondon, M.A., Lehmann, J., Ramirez, J., Hurtado, M., 2007. Biological nitrogen fixation by common beans (Phaseolus vulgaris L.) increases with biochar additions. Biology and fertility of soils 43, 699-708.

Steinbeiss, S., Gleixner, G., Antonietti, M., 2009. Effect of biochar amendment on soil carbon balance and soil microbial activity. Soil Biology and Biochemistry, 41(6), 1301-1310.

Sukartono, W.H., Kusauma, Z., Nugroho, W.H., 2011. Soil fertility status, nutrient uptake and maize (Zea mays L.) yield following biochar and cattle manure application on sandy soils of Lombok, Indonesia. Journal of Tropical Agriculture 49, 47-52.

Uzoma, K.C., Jnoue, M., Andry, H., Fujimaki, H., Zahoor, A., Nishihara, E. 2011. Effect of cow manure biochar on maize productivity under sandy soil condition. Soil Use and Management 27, 205-212. 